\title{
Hydrogeochemical evolution and potability evaluation of saline contaminated coastal aquifer system of Rajnagar, Odisha, India: A geospatial perspective
}

\author{
P P DAS ${ }^{1, *} \mathbb{D}, \mathrm{H}$ K SAhoo $^{1}$ and P P Mohapatra ${ }^{2}$ \\ ${ }^{1}$ Department of Geology, Utkal University, Bhubaneswar, Odisha 751 004, India. \\ ${ }^{2}$ Department of Geology, Ravenshaw University, Cuttack, Odisha 753 003, India. \\ *Corresponding author.e-mail: prabhuprasaddas@gmail.com
}

The present article reports the results of a comprehensive hydrogeochemical study carried out across the coastal aquifer system of Rajnagar block, Kendrapara district, Odisha, India. The research involved collection of representative groundwater samples during the pre- and post-monsoon seasons with in situ as well as laboratory measurement of various hydrogeochemical variables. Analysis of the subsurface water samples portrays an alkali dominated water type during the pre-monsoon season whereas alkaline earth has a significantly increased influence during the post-monsoon period. However, the aquifer system displays an even distribution of strong and weak acids for both the monsoonal regimes. The hydrogeochemistry is controlled by aquifer lithology with a general occurrence of ion exchange and acid-base reaction processes across the study area. Spatial disposition of major cations indicates freshening of this coastal aquifer system in S-N and SW-NE directions. Potability analysis of the samples is suggestive of widespread unsuitability for domestic, agriculture and industrial uses. The extensive occurrence of salinity hazards, sodium hazards and magnesium hazards across the terrain makes the groundwater unsafe for domestic and agricultural utilization while industrial potability analysis suggests the aquifer system is moderately corrosive but non-incrusting. Post-monsoon however, the subsurface waters display a general decrease in hazardous nature with increased suitability for various uses.

\section{Introduction}

The estimation, exploitation, development, monitoring and management of groundwater bodies assume utmost significance purely from a lesser degree of contamination perspective. Hence, the assessment of subsurface water potability forms an important research domain, and new evaluative procedures are continuously proposed for this assessment (Wilcox 1955; Ophori and Toth 1989; Jianhang et al. 2004; Crévecoeur et al. 2011; Li et al. 2012). In turn, this involves the evaluation of quality parameters of subsurface water including the physical, biological, chemical and radiological aspects. Appreciation of hydrogeochemistry of coastal aquifer systems with regard to space and time is very challenging due to the lack of definitive understanding of the interaction between subsurface water with its ambient environment and the inherent associated spatial flow patterns.

Research work undertaken in the area by Shukla (2011), Shukla et al. (2010), Sahoo and Mohapatra (2010), Das and Sahoo (2014), Das et al. (2016), etc., along with the ones undertaken by leading agencies of the country and the state including the Central Groundwater Board, Government of India (CGWB), Rural Water Supply and Sanitary Engineering, Government of Odisha (RWSS),

Keywords. Hydrogeochemistry; aquifer; alkali; potability; cation exchange. 
Groundwater Survey \& Investigation, Government of Odisha (GWS \& I), etc., have focused on groundwater prospecting along the coastal tracts of Odisha. The coast of Odisha, including the present study area, belongs to thick Quaternary alluvium deposits, which are very complex with respect to their depositional history as well as sediment composition. The current study was undertaken with an aim to appreciate the (1) hydrogeochemistry (2) hydrodynamics and (3) saline water influences on the eastern part of Kendrapara district of Odisha, India and to build a baseline dataset for future management and monitoring strategies as well as policy making decisions. As a part of this groundwater resource assessment, the present article reports a comprehensive assessment of the alluvial aquifers of Rajnagar block from a water potability perspective, with respect to domestic, irrigation and industrial use. In addition to potability evaluation, the article assesses the geochemical controls on groundwater composition, as well as the sources thereof.

\section{Site of research}

The present research looks into the hydrogeochemistry of the coastal aquifer system of Rajnagar block, Kendrapara district, Odisha, India. The various physiographical and geological attributes of the region are described below.

\subsection{Location}

The Rajnagar alluvial aquifer system lies in the eastern part of the Kendrapara district along the coastal tracts of Odisha (figure 1a). The study area encompasses approximately $650 \mathrm{~km}^{2}$ with a perimeter of about $185 \mathrm{~km}$. The river Brahmani gushes across the terrain before merging with the Bay of Bengal and has shaped the erosional as well as depositional features of the region along with the marine influences of the sea which forms the eastern boundary. Rajnagar has a very close proximity to the Paradeep port, one of the major industrial hubs of Odisha, along the coast (figure 1a). In contrast to the port region, Rajnagar has not witnessed any kind of industrialisation (small or large scale) till date. In the absence of industries, agriculture and fishing have been the lifeline of the population and hence is primarily reliant on the monsoon for irrigation, which also is a very erratic climatic phenomenon. Added to this, the region is often distressed by natural catastrophes such as cyclones. The study area lags way behind other coastal areas of the state, in an economic perspective, and is considered as one of the most socioeconomically backward regions. A vast growth of mangroves is witnessed along the coast. The spatial limits of the area are approximately from $86.65^{\circ}$ $87.10^{\circ} \mathrm{E}$ longitude and $20.50^{\circ}-20.79^{\circ} \mathrm{N}$ latitude.

\subsection{Geomorphology}

Topographically, the terrain is very even with the elements of slope, aspect and curvature indicating a very gently east and northeast sloping landscape (Das and Sahoo 2014). Physiographically, the study area is broadly classified into (a) coastal saline marshy tract and (b) gently sloping plain (CGWB Technical report 2002; GSI Technical report 2011). The marshy tract adjacent to the coast is a long and narrow alluvial tract. The width of this unit varies from 3 to $15 \mathrm{~km}$ and is intersected by tidal streams across its length. The tract is primarily covered by shrubby vegetation and display fluviomarine influence in the form of beach sand deposits, tidal flat deposits, channel sand and newer sand dunes (figure 1b). The occurrence of a thin layer of medium to fine-grained white beach sand over the mud flats is suggestive of active sedimentation. Brahmani and its distributaries have given rise to various channel deposits composed of sand, silt and clay. Older tidal flats consisting of very fine silt and clay occur within the interfluves. The northern and northeastern part of the study area exhibit vast deposits of mudflats, wetlands and tidal swamps over which extensive stretches of mangrove forests are present. Older beach ridges and newer dunes of varying relief, between 3 and $6 \mathrm{~m}$, are found parallel to the coast (figure $1 \mathrm{~b}$ ). The dunes exhibit gentle seaward and steeper landward slopes. The alluvial plains occur along the southwestern part of the study area with a very gentle slope to the west of marshy tract (figure 1b). The average elevation of this plain land is between 2 and $6 \mathrm{~m}$ above mean sea level (AMSL) with an easterly/southeasterly slope of $1.5 \mathrm{~m} / \mathrm{km}$. This geomorphic unit of the study area is very fertile consisting of active floodplain deposits of present day formation and it is no wonder why this region displays an extremely dense human population.

\subsection{Geology}

Recent alluvium and sand bodies of Quaternary age, exposed in the study area, belong to the Burahbalang and Bankigarh Formations (Mishra et al. 2003; GSI Technical report 2011; GSI Miscellaneous publication 2012). These are fluvial to marine alluvial deposits. The Bankigarh Formation is primarily composed of old sand dunes, fluvial silt, fluvial and marine clay and deltaic deposits covering the entire southern part of the study area (figure 1c). The lithology of the northern part is composed of alternating floodplain layers of sand and silt, recent sand dunes and marine 
deposits belonging to the Burahbalang Formation (figure 1c). Exploratory drilling carried out for groundwater exploitation indicates the presence of older alluvium, fossiliferous limestone and MioPliocene deposits at deeper depths (CGWB Technical report 2002). The generalised stratigraphic sequence of this coastal aquifer system is given below (CGWB Technical report 2002; Mishra et al. 2003; GSI Technical report 2011).

\begin{tabular}{lll}
\hline Period & \multicolumn{1}{c}{ Epoch } & \multicolumn{1}{c}{ Formation } \\
\hline $\begin{array}{l}\text { Cenozoic Era } \\
\text { Quarternary }\end{array}$ & $\begin{array}{l}\text { Recent to } \\
\text { Pleistocene }\end{array}$ & $\begin{array}{l}\text { Recent and older alluvium, } \\
\text { sand dunes, etc. (Burhabalang } \\
\text { Formation) }\end{array}$ \\
Upper & Mio-Pliocene & $\begin{array}{l}\text { Brown, yellow, gray clays, silt } \\
\text { (Kaimundi Formation) } \\
\text { Tertiary }\end{array}$ \\
& & $\begin{array}{l}\text { Sand, gravels, mudstone, } \\
\text { molluscan shell, fossiliferous } \\
\text { limestones, etc. (Bankigarh } \\
\text { Formation) }\end{array}$ \\
\hline
\end{tabular}

Various geophysical surveys including the electrical resistivity and gamma ray logging carried out for the study area indicate the presence of alternating clayey and granular horizons (Mishra et al. 2003; Shukla et al. 2010, 2013; Shukla 2011). The exploratory wells that had been drilled for groundwater exploitation were up to $350 \mathrm{~m}$ deep. All the boreholes of these explorations ended in sedimentary layers. The clayey layers are plastic in general, but silty clays are present sporadically across the study area. Yellow to brown clays occur up to depths of 80-90 m, whereas grey to dark grey ones are encountered below this depth. The granular horizons are sandwiched between the clay beds and are the chief horizons of subsurface water. Lithologically, they consist of fine to coarse sand and fine gravels. The thickness, as well as the proportion of these clayey and granular layers, varies considerably in the entire study area. While thick layers (clay or granular) are generally encountered up to depths of 200-250 m, deeper depths display

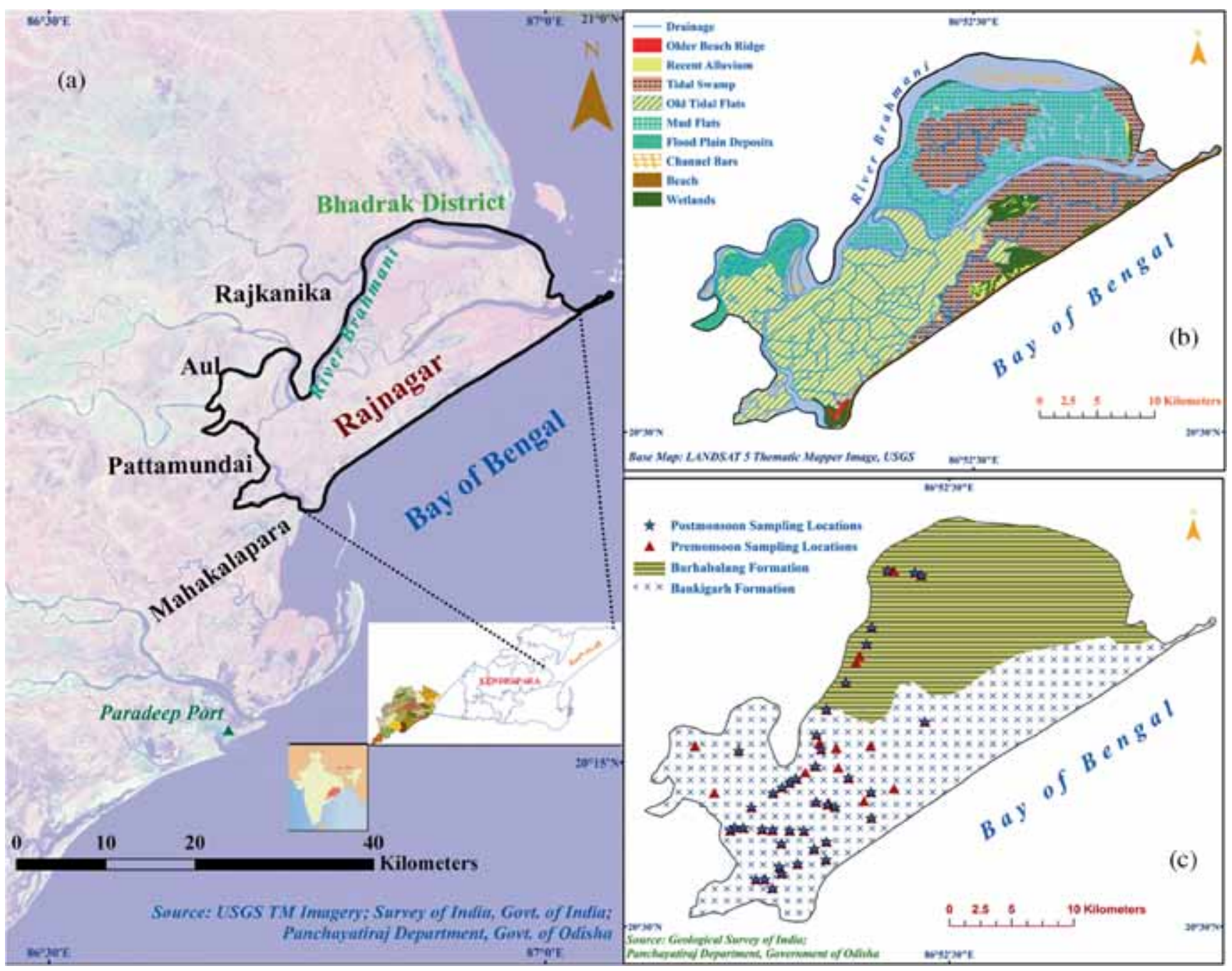

Figure 1. (a) Location, (b) geomorphology and (c) geology of the study area. 
much thinner horizons (1-3 m). Granular horizons dominate the subsurface composition of the study area. However, clayey layers, as well as the proportion of gravels in granular horizons, display a diminishing trend from west to east.

\subsection{Hydrogeology}

The fresh water aquifer system of the coastal tract of Odisha can be broadly classified into the following categories: (i) shallow aquifers $(<150 \mathrm{~m}$ depth), (ii) intermediate aquifers (150-300 m) and (iii) deep aquifers $(>300 \mathrm{~m})$. Based on these depth ranges, the collected samples tap the intermediate groundwater horizons. However, the thickness of the freshwater zones does not vary considerably. The shallow fresh aquifers have a negligible thickness throughout the entire study area due to the occurrence of thick clay layers near the surface. In abandoned paleochannels and dunes, however, the freshwater horizons occur up to depths of 10$15 \mathrm{~m}$ with an average thickness of $5-6 \mathrm{~m}$ (CGWB Technical Report 2002). There occurs an extensive and continuous saline zone below this shallow fresh water horizon across the study area up to depths of 120-150 m. The intermediate fresh water horizon is sandwiched between this shallow saline zone and the deep saline zone. The depth of this continuous fresh water layer remains consistent up to depths of $250 \mathrm{~m}$, with the central and southern territory displaying a slightly greater thickness. No exploratory endeavour has encountered any fresh water horizon below this depth and the subsurface water is essentially saline (Shukla 2011). The subsurface lateral disposition of fresh and saline aquifer horizons indicates a general saline influence across the study area (figure 2).

\section{Materials and methodology}

The current research involved a hydrochemical analysis of 93 collected representative groundwater samples of pre-monsoon and post-monsoon seasons of 2013. The various methodological approaches followed during the collection and analysis of the present study are described below.

\subsection{Representative groundwater sampling}

A total of 53 groundwater samples were collected, taking into account the geology, topography, hydrology and cultural set-up of the study area (figure 1c). However, post-monsoon, many of the tube wells became inaccessible or damaged for sample collection. As a result, a total of 40 wells were sampled for water quality analysis (figure 1c). The sample collection endeavour involved the use of $300 \mathrm{ml}$ polyethene low-density narrow mouth bottles (USP Class IV) with leak-proof and airtight lid. The collection of water samples were carried out following the standard procedures (Brown et al. 1974; Hem 1985; APHA 1985; Jain and Bhatia 1987).

\subsection{Geochemical analysis}

Measurement of physico-chemical variables of $\mathrm{pH}$ and electrical conductance (EC) was carried out

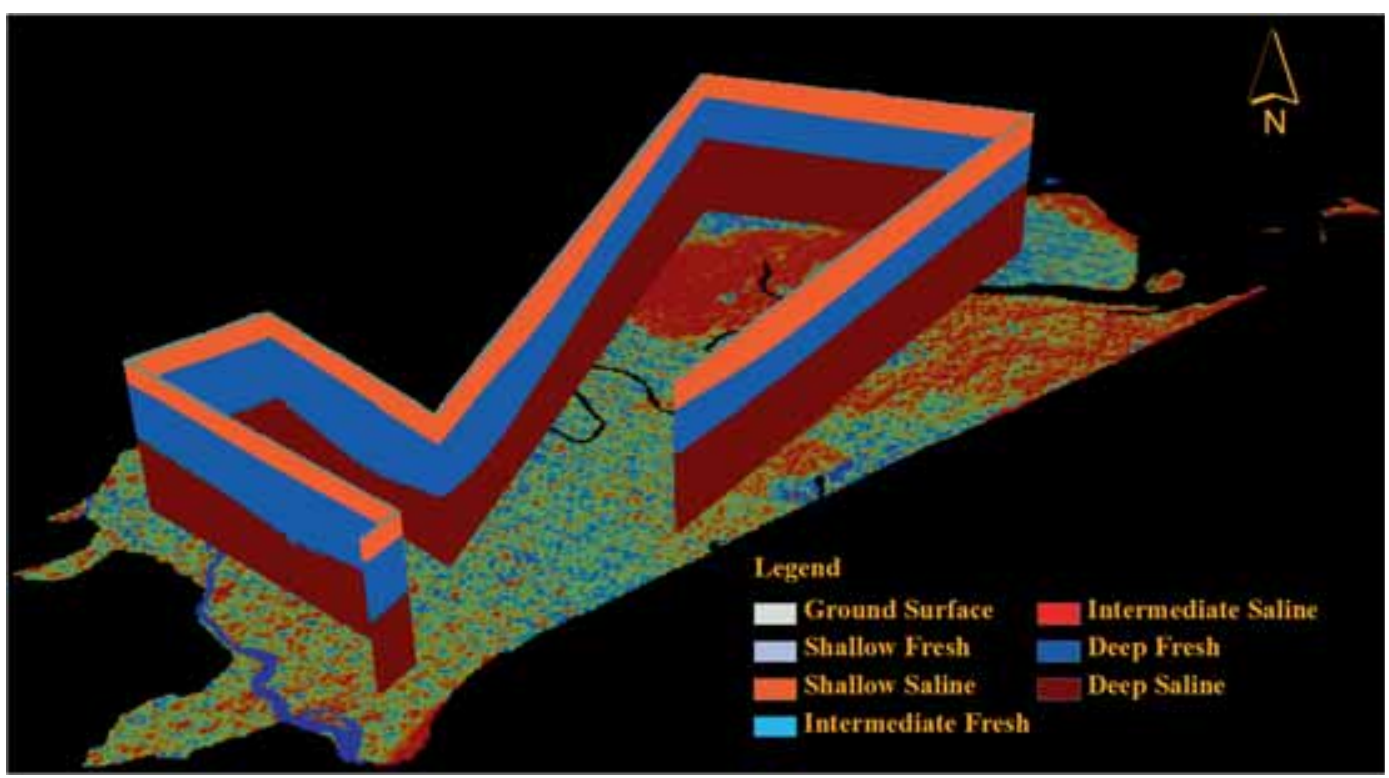

Figure 2. Subsurface disposition of saline and fresh water horizons of the study area (depth difference between the tops of adjacent water horizons is the applied vertical exaggeration with the base height of deep saline horizon taken as $-650 \mathrm{~m}$ and ground surface elevation derived from the SRTM data). 
in situ. The rest of the hydrochemical variables were estimated following standard protocols as defined by Brown et al. (1974), Trivedi and Goel 1984, APHA (1985) and Jain and Bhatia (1987). The concentration of total alkalinity (TA), total hardness $(\mathrm{TH})$, and calcium $\left(\mathrm{Ca}^{2+}\right)$, chloride $\left(\mathrm{Cl}^{-}\right)$, carbonate $\left(\mathrm{CO}_{3}^{2-}\right)$ and bicarbonate $\left(\mathrm{HCO}_{3}^{-}\right)$ions were determined by volumetric titration method. Measurement of sodium $\left(\mathrm{Na}^{+}\right)$and potassium $\left(\mathrm{K}^{+}\right)$concentrations were carried out by flamephotometer. Double beam spectrophotometer was used for the estimation of sulphate $\left(\mathrm{SO}_{4}^{2-}\right)$ activity. Magnesium concentration in the groundwater samples was determined from that of $\mathrm{TH}$ and calcium $\left[\mathrm{Mg}^{2+}=\left(\mathrm{TH}-2.497 \times \mathrm{Ca}^{2+}\right) / 4.151\right]$. The concentrations of the variables were reported in milligram per litre (mg/l) except for EC (micro Siemens per centimetre, $\mu \mathrm{s} / \mathrm{cm}$ ) and $\mathrm{pH}$. This unit of measurement of variable concentrations was converted to meq/l for hydrogeochemical analysis, wherever necessary.

\subsection{Geospatial analysis}

The analysis involved the use of technologies of Remote Sensing, Geographical Information System (GIS) and Global Positioning System (GPS). The acquired satellite images (United States Geological Survey), SOI toposheets and geological map (GSI) were digitised to extract various thematic layers. GPS formed a vital element of the subsurface water sampling in providing the positional characteristic of sampled tube wells. Spatial interpolation of hydrochemical variables and ionic ratios thereof was done in GIS to create Digital Elevation Models (DEMs) to help understand the hydrodynamic behaviour and hydrogeochemical nature of the groundwater. 'Topo to Raster' interpolating tool based on 'iterative finite difference interpolation technique' was followed, for individual variable raster creation. The tool is specifically designed to create hydrologically correct DEMs that precisely retain natural drainage surfaces and preserves the natural ridgelines and stream networks. As the variables, investigated for the present study relates to hydrodynamics of the aquifer system, the tool was used to create DEMs of physicochemical variables, wherein the concentrations represent ' $z$ ' values. The surface representation of individual hydrochemical variables follows a classified or stretched form based on the histogram equalisation technique for the present research.

\section{Results and discussion}

The study involved the analysis of 93 groundwater samples (53 pre-monsoon and 40 post-monsoon samples). Descriptive statistics of the analysed samples is given in table 1 and the results are discussed in the light of evolution and potability, in the following sections.

\subsection{Geochemical evolution}

Hydrochemical analysis of collected groundwater samples displays a consistent higher TDS in both the monsoonal seasons and a general increase in $\mathrm{Cl}^{-}$concentration during the post-monsoon period (which can be inferred from the lower range and higher average, table 1) indicating a saline influence on this coastal aquifer. There is a distinct decrease in acidity with all the samples of post-monsoon period belonging to basic category (table 1). All the samples of the pre-monsoon period also come within the potable $\mathrm{pH}$ range

Table 1. Descriptive statistics of the hydro-geochemical constituents and potability indices of the study area (concentration of the variables are in $\mathrm{mg} / \mathrm{l}$, except $\mathrm{pH}$ and $\mathrm{EC}$ in $\mu \mathrm{s} / \mathrm{cm}$ ).

\begin{tabular}{|c|c|c|c|c|c|c|c|c|c|c|}
\hline \multirow[b]{2}{*}{ Variable } & \multicolumn{2}{|c|}{ Observations } & \multicolumn{2}{|c|}{ Minimum } & \multicolumn{2}{|c|}{ Maximum } & \multicolumn{2}{|c|}{ Mean } & \multicolumn{2}{|c|}{ Standard deviation } \\
\hline & $\begin{array}{c}\text { Pre- } \\
\text { monsoon }\end{array}$ & $\begin{array}{c}\text { Post- } \\
\text { monsoon }\end{array}$ & $\begin{array}{c}\text { Pre- } \\
\text { monsoon }\end{array}$ & $\begin{array}{c}\text { Post- } \\
\text { monsoon }\end{array}$ & $\begin{array}{c}\text { Pre- } \\
\text { monsoon }\end{array}$ & $\begin{array}{c}\text { Post- } \\
\text { monsoon }\end{array}$ & $\begin{array}{c}\text { Pre- } \\
\text { monsoon }\end{array}$ & $\begin{array}{c}\text { Post- } \\
\text { monsoon }\end{array}$ & $\begin{array}{c}\text { Pre- } \\
\text { monsoon }\end{array}$ & $\begin{array}{c}\text { Post- } \\
\text { monsoon }\end{array}$ \\
\hline $\mathrm{pH}$ & 53 & 40 & 6.660 & 7.190 & 7.430 & 7.880 & 6.937 & 7.387 & 0.153 & 0.169 \\
\hline $\mathrm{EC}$ & 53 & 40 & 938.000 & 930.000 & 2060.000 & 1800.000 & 1147.377 & 1138.700 & 192.441 & 204.028 \\
\hline TDS & 53 & 40 & 600.320 & 595.200 & 1318.400 & 1152.000 & 734.322 & 728.768 & 123.162 & 130.578 \\
\hline $\mathrm{Na}^{+}$ & 53 & 40 & 80.300 & 103.510 & 233.310 & 496.320 & 112.514 & 159.338 & 23.946 & 63.681 \\
\hline $\mathrm{K}^{+}$ & 53 & 40 & 3.090 & 5.820 & 10.410 & 14.370 & 7.473 & 8.707 & 1.931 & 2.104 \\
\hline $\mathrm{Ca}^{2+}$ & 53 & 40 & 10.000 & 10.000 & 80.000 & 75.000 & 40.708 & 41.100 & 19.271 & 16.133 \\
\hline Cl- & 53 & 40 & 13.000 & 45.000 & 415.000 & 320.000 & 111.358 & 122.375 & 67.186 & 72.792 \\
\hline $\mathrm{TH}$ & 53 & 40 & 110.000 & 205.000 & 225.000 & 500.000 & 159.245 & 298.250 & 26.227 & 59.545 \\
\hline TA & 53 & 40 & 270.000 & 225.000 & 620.000 & 480.000 & 351.698 & 387.025 & 52.431 & 48.937 \\
\hline $\mathrm{CO}_{3}^{2-}$ & 53 & 40 & 0.000 & 0.000 & 24.000 & 0.000 & 6.226 & 0.000 & 9.187 & 0.000 \\
\hline $\mathrm{HCO}_{3}^{-}$ & 53 & 40 & 152.500 & 134.200 & 231.800 & 268.400 & 192.092 & 210.145 & 18.324 & 23.684 \\
\hline $\mathrm{SO}_{4}^{2-}$ & 53 & 40 & 17.350 & 20.100 & 67.360 & 68.700 & 41.930 & 43.730 & 10.260 & 14.201 \\
\hline $\mathrm{Mg}^{2+}$ & 53 & 40 & 0.000 & 21.341 & 38.415 & 94.207 & 14.019 & 47.683 & 10.683 & 15.214 \\
\hline
\end{tabular}


of $6.5-8.5$. This increasing alkaline nature of the post-monsoon samples signifies the occurrence of predominant acid-base reactions within the shallow subsurface unsaturated horizon. The subsurface waters display little variation in EC and TDS activity during the monsoonal season (table 1). In fact, there seems to be a slight decrease in the total ionic concentration of the aquifer system postmonsoon. This observation is amply supported by the nearly constant/unchanged variable concentrations with respect to $\mathrm{K}^{+}, \mathrm{Ca}^{2+}, \mathrm{Cl}^{-}, \mathrm{SO}_{4}^{2-}$ and $\mathrm{HCO}_{3}^{-}$. Increase in concentration is portrayed by the elements $\mathrm{Na}^{+}$and $\mathrm{Mg}^{2+}$.

Molluscan limestones have been encountered at a depth range of 145-290 malong the western part of the block as well asin adjacent blocks of Pattamundai and Kendrapara (CGWB Technical Report 2002), and calcium carbonate concretions in the alluviummight have resulted in the carbonate dissolution in the aquifers. However, the water samples of Rajnagar do not display any significantvariation in $\mathrm{Ca}^{2+}$ concentrations during the post-monsoon period (table 1); moreover, there is a distinct increase in $\mathrm{Na}^{+}$concentration along the western part of the study area (figure $3 \mathrm{c}, \mathrm{d}$ ). The aquifer system also exhibits a characteristic increase in $\mathrm{Mg}^{2+}$ (figure $3 \mathrm{e}, \mathrm{f}$ ) concentration along the eastern part which is synchronous with the higher concentration of $\mathrm{K}^{+}$(figure $3 \mathrm{~g}, \mathrm{~h}$ ) and reduced concentration of $\mathrm{Ca}^{2+}$ (figure $3 \mathrm{a}, \mathrm{b}$ ) during the post-monsoon period. These characteristic variations of major hydrochemical variables point towards significant cation exchange processes which are indicative of freshening of this saline contaminated aquifer system. When overlaid on the piezometric head contours of the study area, these exchange processes signify $\mathrm{Ca}^{2+} / \mathrm{Na}^{+}$exchange in the regions of maximum recharge along the western and northern part of the study area, from base flow recharge of the river Brahmani in conjunction with recharging rain water. Freshening occurs primarily in an S-N and SW-NE directions. This cation exchange, in a gradational manner, gives rise to an increased $\mathrm{Mg}^{2+}$ and $\mathrm{K}^{+}$concentration around the regions of lowest recharge in the central and eastern parts by which time the $\mathrm{Ca}^{2+} / \mathrm{Na}^{+}$ exchange nears equilibrium and $\mathrm{Mg}^{2+}$ and $\mathrm{K}^{+}$are exchanged with the recharging fresh water $\mathrm{Ca}^{2+}$. The occurrence of continuous shallow subsurface saline layers across the block (figure 2), as well as the consistent $\mathrm{Cl}^{-}$concentration (table 1), for both the monsoonal periods indicate a significant formational water influence on the deeper fresh water horizons during the post-monsoon period. However, the extreme northern and southern regions of the study area do not display any significant trend with respect to cationic distribution and are suggestive of possible sites of salt water ingress.
All the above-mentioned processes of ion exchanges and carbonate dissolutions are known to generate $\mathrm{CO}_{2}$ and as a result, the groundwater displays consistently greater $\mathrm{HCO}_{3}^{-}$and TA concentrations. $\mathrm{CO}_{3}^{2-}$ is practically absent except for minor occurrences pre-monsoon and is a reflection of the observed $\mathrm{pH}$ range of the water samples which is well below the crossover $\mathrm{pH}$ value of 10.33 for $\mathrm{HCO}_{3}^{-}$and $\mathrm{CO}_{3}^{2-}$.

The chemical composition of groundwater indicates an alkali cation dominated water type with spatially restricted weak and strong acids for the study area during the pre-monsoon period, whereas postmonsoon, there seems to be an increased influence of alkaline earth. This inference is in line with two of the most widely used graphic representations involving the chemical evolution of groundwater, i.e., Piper's (1944) and Chadha's (1999) diagrams for the study area. Chadha's classification for the aquifer system displays a distinct shift in the post-monsoon period wherein $42.5 \%$ of samples plot, within the subfields of 1,5 and 6 , indicate a significant increase in the influence of alkaline earth on subsurface hydrochemistry, in contrast to the complete absence of any sample within these fields for the pre-monsoon season (figure 4). However, there is almost equal distribution of samples within the strong and weak acidic fields of the diagram for both the seasons.

Similar to that of Chadha's classification, the samples display a complete predominance of alkali influence on the hydrochemistry of subsurface water during the pre-monsoon season in Piper's classification with $58.5 \%$ of the samples coming within the subfield of 7 and the rest within that of subfield 9 (figure 5). The subfield 7 indicates predominance of noncarbonated alkali. Hence, the hydrochemistry of the subsurface water is primarily influenced by alkalis and strong acids. However, during the post-monsoon season, $32.5 \%$ of the samples belong to the subfield 7 , whereas $27.5 \%$ of the samples plot within subfield 5, indicating a significantly increased influence of alkaline earth and weak acids. Thus, this distribution of the cations and anions for both the diagrams indicates a $\mathrm{Na}^{-}$ $\mathrm{Cl}$ and $\mathrm{Na}-\mathrm{HCO}_{3}$ dominated water types for the pre-monsoon period, whereas, there exists an intermixing of $\mathrm{Na}-\mathrm{Cl}, \mathrm{Na}-\mathrm{HCO}_{3}$ and $\mathrm{Mg}-\mathrm{HCO}_{3}$ water types during the post-monsoon season. A closer look at the plotting of the samples within the Piper trilinear diagram with respect to their distance from the coast indicates that near-shore aquifers $(<10 \mathrm{~km})$ have a greater saline influence, as well as greater freshening changes, than the far-shore aquifers $(>10 \mathrm{~km})$ during the post-monsoon season (figure $5 \mathrm{c}, \mathrm{d}$ ).

Based on the relative abundance of anions and cations, Gibbs (1970) proposed three distinct origins 

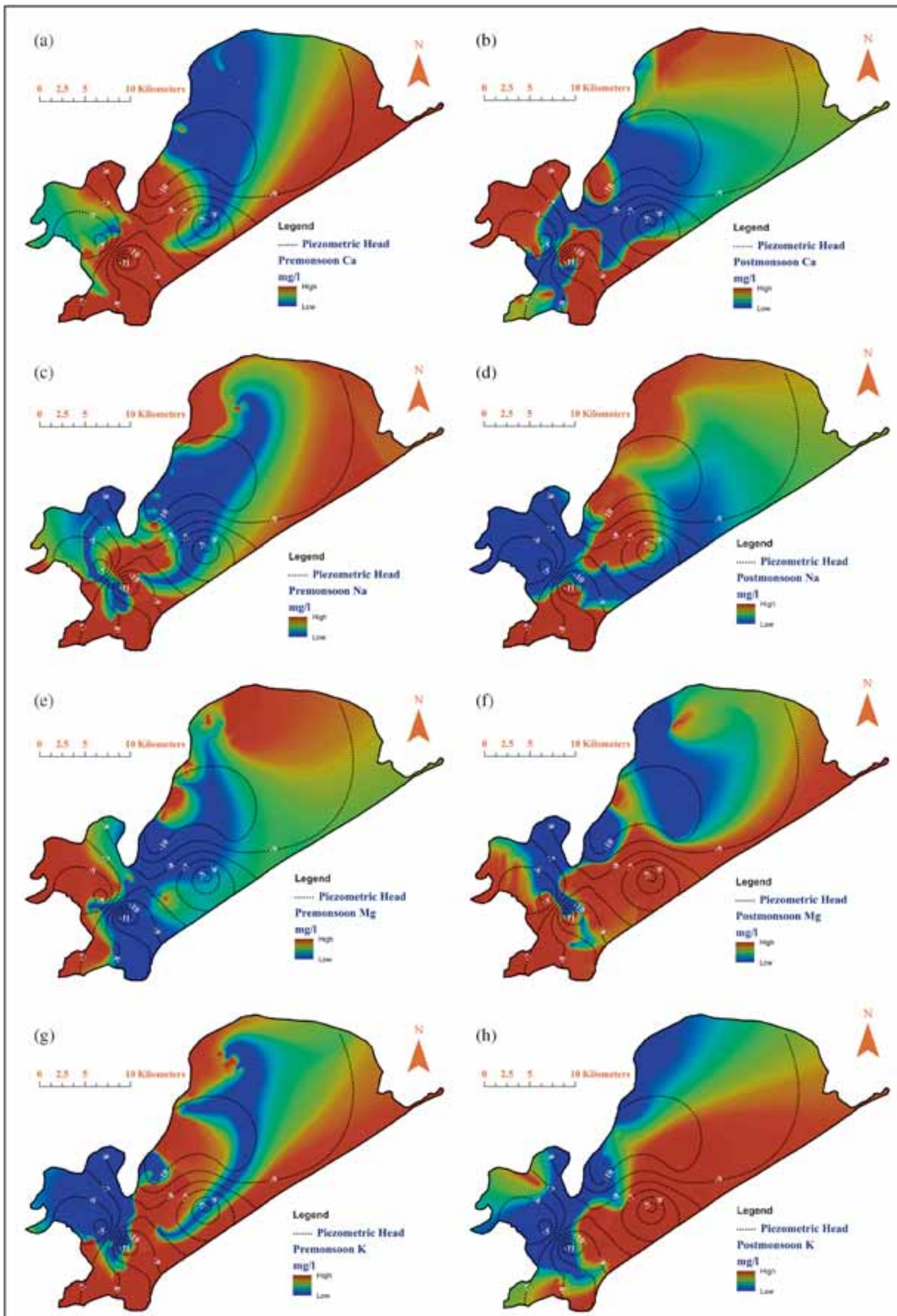

Figure 3. Spatial distribution of $\mathrm{Ca}^{2+}\left[(\mathbf{a})\right.$ pre-monsoon, (b) post-monsoon]; $\mathrm{Na}^{+}[(\mathbf{c})$ pre-monsoon, (d) post-monsoon]; $\mathrm{Mg}^{2+}\left[(\mathbf{e})\right.$ pre-monsoon, (f) post-monsoon]; $\mathrm{K}^{+}[(\mathbf{g})$ pre-monsoon, (h) post-monsoon)] concentrations of the study area. 


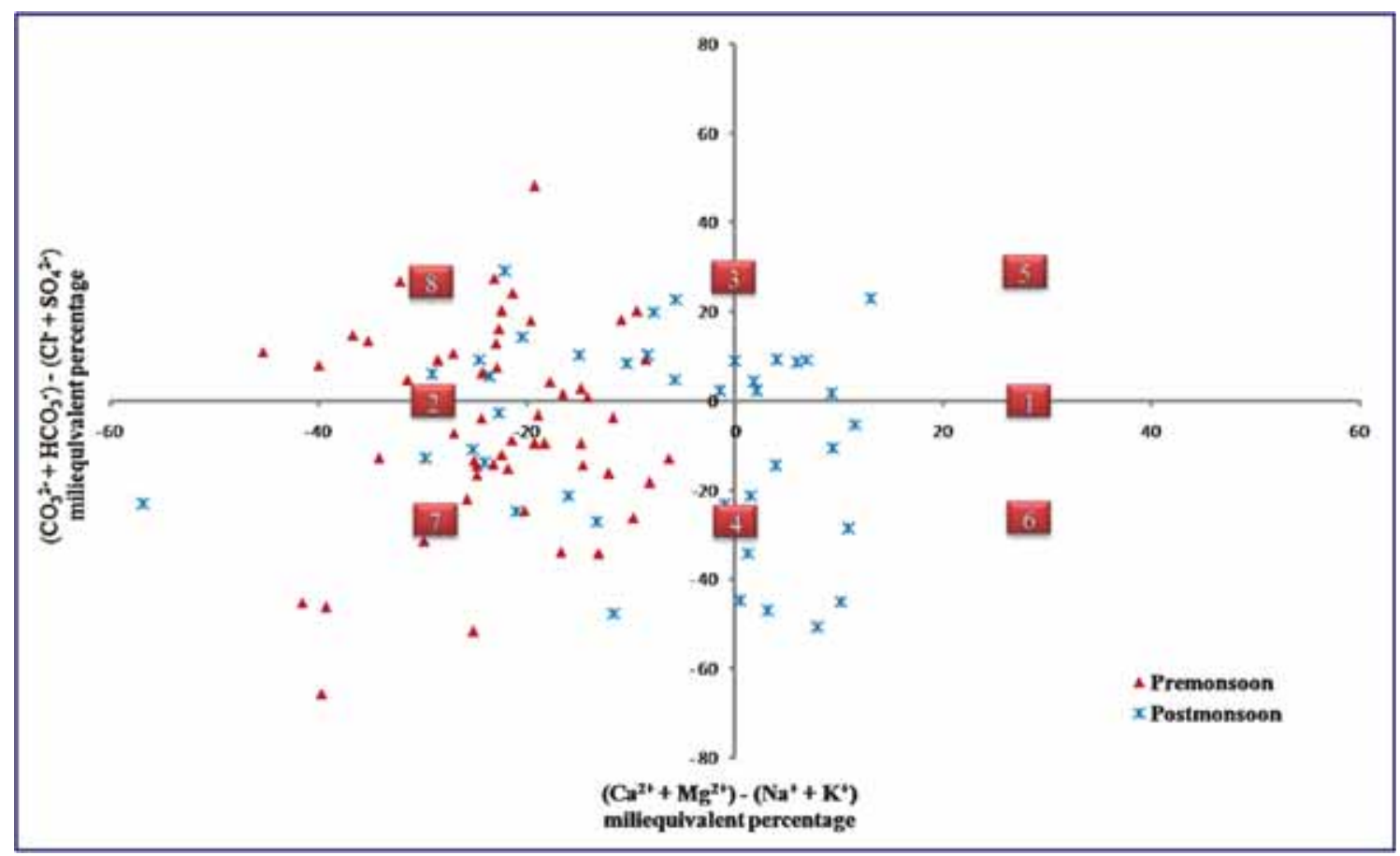

Figure 4. Distribution of groundwater types based on Chadha's classification for the study area.

of hydrochemistry such as 'rock dominance', 'evaporation/crystallisation dominance' and 'precipitation dominance'. The diagram takes into account two separate diagrams, wherein the interrelationship between the cationic ratio of $\mathrm{Na}^{+} /\left(\mathrm{Ca}^{2+}+\right.$ $\left.\mathrm{Na}^{+}\right)$and the anionic ratio of $\mathrm{Cl}^{-} /\left(\mathrm{Cl}^{-}+\mathrm{HCO}_{3}^{-}\right)$ are plotted against TDS. The cationic plotting of the groundwater samples for the study area indicates a dominating influence of aquifer lithology on groundwater chemistry (figure 6). Although the anionic ratio of the samples plot within the rock dominance field, it displays a significant influence of evaporation/crystallisation and precipitation processes. Hence, it can be inferred that there is a general occurrence of ion exchange and acidbase reaction processes across this coastal alluvial aquifer system.

A look into the interrelationship between physico-chemical variables portrays a significant influence of $\mathrm{Na}^{+}$and $\mathrm{Cl}^{-}$on the total ionic concentration during both the monsoonal periods (tables 2, 3). There is, however, a significantly increased influence of $\mathrm{Cl}^{-}$and $\mathrm{Mg}^{2+}$ during the post-monsoon season. This observation testifies the earlier inferences of salt water/formational water invasion as well as greater alkaline earth influence on the aquifer hydrochemistry. The strong negative relationship between $\mathrm{Mg}^{2+}$ and $\mathrm{Ca}^{2+}$ during the pre-monsoon season is suggestive of significant cationic exchange between these two variables from formational water influence.

\subsection{Potability evaluation}

Aquifer lithology has a significant influence on the groundwater chemistry. Since the subsurface water passes through various geologically and chemically complex terrains during its course of movement, a single influencing factor cannot be ascribed to infer its chemical composition. This is the reason why, a host of ionic ratios as well as graphic representations depicting the interrelationship between different analytes and combinations thereof, have been proposed for the quality assessment purpose. The following section gives a comprehensive detailed analysis of the aquifer hydrochemistry with respect to its potability for domestic, agriculture and industrial purposes.

\subsubsection{Domestic use}

The dynamic and complex nature of the study area is well gauged from its fluviomarine induced hydrogeology. Taking into perspective the socioeconomic backwardness of the region and complete absence of industry, the variables taken into consideration for domestic potability evaluation are $\mathrm{pH}, \mathrm{TDS}, \mathrm{TH}, \mathrm{Ca}^{2+}, \mathrm{Mg}^{2+}, \mathrm{Cl}^{-}$and $\mathrm{SO}_{4}^{2-}$. Water quality with respect to drinking and other domestic purposes has been evaluated as per the Bureau of Indian Standards (2012). The range and percentage of samples for pre-monsoon and post-monsoon seasons are given in table 4 . The observation indicates a general unsuitability of the 


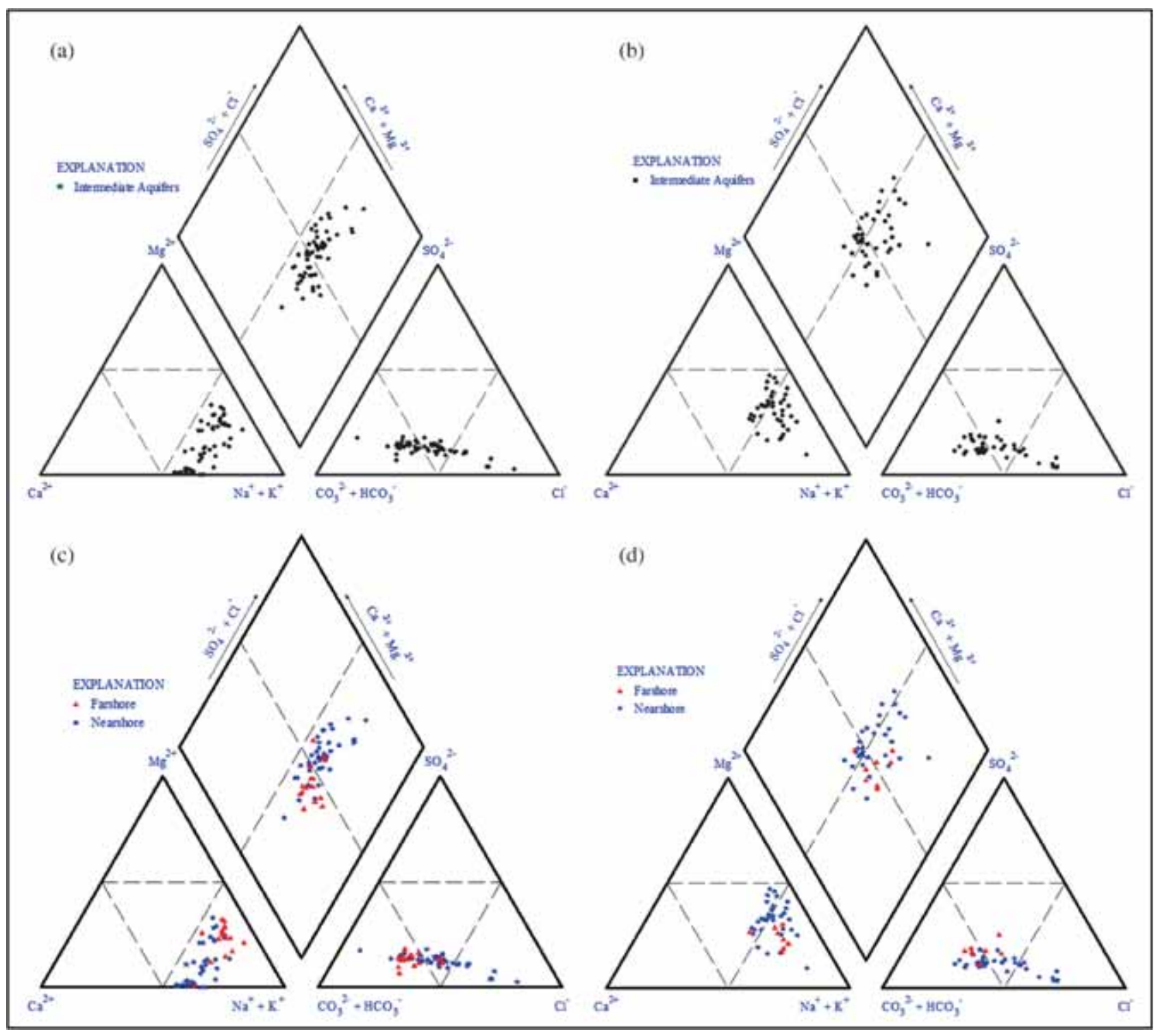

Figure 5. Distribution of groundwater types based on Piper's classification for the study area (a, c) pre-monsoon and (b, d) post-monsoon.

subsurface water of the study area with regard to domestic potability (table 4). All samples of the pre-monsoon, as well as post-monsoon period, display TDS concentrations beyond the acceptable limit (AL) of $500 \mathrm{mg} / \mathrm{l}$, but within the permissible limit (PL) of $2000 \mathrm{mg} / \mathrm{l}$ (table 4). The area also displays a profound increased unsafe characteristic with regard to $\mathrm{Mg}^{2+}$ content, post-monsoon (>30 mg/l, 87.5\%, figure $7 \mathrm{~b}$ ) in contrast to a general suitability ( $<30 \mathrm{mg} / 1,94.3 \%$, figure $7 \mathrm{a}$ ) during the pre-monsoon period (table 4). This, in turn, gives rise to widespread hard water regimes across the region with all the samples belonging to 'hard' or 'very hard' category, and all the samples exceed the $\mathrm{AL}$ for drinking purpose (table 4 , figure $7 \mathrm{c}$, d). However, the degree of unsuitability is somewhat less with regard to $\mathrm{pH}, \mathrm{Ca}^{2+}, \mathrm{SO}_{4}^{2-}$ and
$\mathrm{Cl}^{-}$(figure 7e, f) in comparison to the $\mathrm{AL}$ as suggested by the BIS (2012) for both the monsoonal periods.

\subsubsection{Agricultural use}

Being one of the mostunderdeveloped regions of the state, agriculturebecomes the lifeline of the people. Hence, irrigationassumes a significant importance in the region's economicstability which is primarily based on monsoonalrainfall. However, this monsoon dependent irrigation suffersdue to its erratic nature. This, in turn, necessitatesa very careful and thorough evaluation of the groundwater resourcesof the region from an irrigation applicability perspective. The primary factors which affect the suitability of groundwater for agriculture are TDS and 


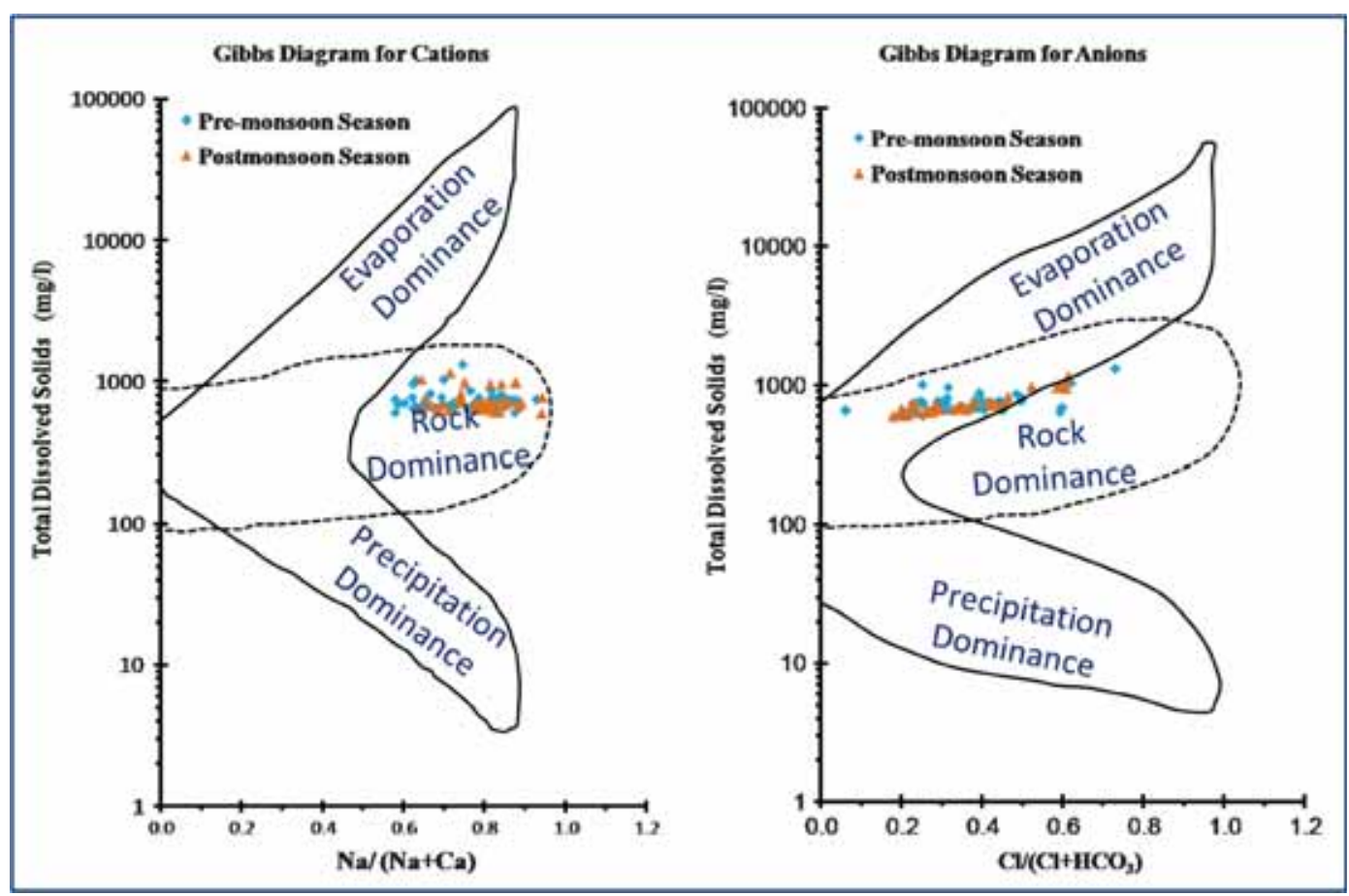

Figure 6. Gibbs' diagram for the study area.

Table 2. Correlation matrix of the chemical constituents for pre-monsoon groundwater samples.

\begin{tabular}{|c|c|c|c|c|c|c|c|c|c|c|c|c|}
\hline & $\mathrm{PH}$ & $\mathrm{EC}$ & TDS & $\mathrm{Na}^{+}$ & $\mathrm{K}^{+}$ & $\mathrm{Ca}^{2+}$ & $\mathrm{Cl}^{-}$ & $\mathrm{TH}$ & $\mathrm{TA}$ & $\mathrm{HCO}_{3}^{-}$ & $\mathrm{SO}_{4}^{2-}$ & $\mathrm{Mg}^{2+}$ \\
\hline $\mathrm{PH}$ & 1.00 & & & & & & & & & & & \\
\hline $\mathrm{EC}$ & 0.38 & 1.00 & & & & & & & & & & \\
\hline TDS & 0.38 & 1.00 & 1.00 & & & & & & & & & \\
\hline $\mathrm{Na}^{+}$ & 0.07 & 0.57 & 0.57 & 1.00 & & & & & & & & \\
\hline $\mathrm{K}^{+}$ & 0.01 & 0.29 & 0.29 & 0.23 & 1.00 & & & & & & & \\
\hline $\mathrm{Ca}^{2+}$ & -0.38 & 0.23 & 0.23 & 0.22 & 0.16 & 1.00 & & & & & & \\
\hline $\mathrm{Cl}^{-}$ & -0.12 & 0.65 & 0.65 & 0.83 & 0.28 & 0.35 & 1.00 & & & & & \\
\hline $\mathrm{TH}$ & -0.15 & 0.45 & 0.45 & 0.35 & 0.25 & 0.43 & 0.50 & 1.00 & & & & \\
\hline TA & 0.21 & -0.19 & -0.19 & -0.29 & -0.10 & -0.27 & -0.45 & -0.21 & 1.00 & & & \\
\hline $\mathrm{HCO}_{3}^{-}$ & 0.35 & -0.12 & -0.12 & -0.34 & -0.06 & -0.55 & -0.56 & -0.25 & 0.53 & 1.00 & & \\
\hline $\mathrm{SO}_{4}^{2-}$ & 0.12 & -0.03 & -0.03 & -0.41 & -0.05 & -0.29 & -0.30 & 0.02 & 0.24 & 0.31 & 1.00 & \\
\hline $\mathrm{Mg}^{2+}$ & 0.33 & 0.02 & 0.02 & -0.04 & -0.03 & -0.84 & -0.08 & 0.12 & 0.18 & 0.46 & 0.33 & 1.00 \\
\hline
\end{tabular}

Table 3. Correlation matrix of the chemical constituents for post-monsoon groundwater samples.

\begin{tabular}{|c|c|c|c|c|c|c|c|c|c|c|c|c|}
\hline & $\mathrm{pH}$ & $\mathrm{EC}$ & TDS & $\mathrm{Na}^{+}$ & $\mathrm{K}^{+}$ & $\mathrm{Ca}^{2+}$ & $\mathrm{Cl}^{-}$ & $\mathrm{TH}$ & TA & $\mathrm{HCO}_{3}^{-}$ & $\mathrm{SO}_{4}^{2-}$ & $\mathrm{Mg}^{2+}$ \\
\hline $\mathrm{pH}$ & 1.00 & & & & & & & & & & & \\
\hline $\mathrm{EC}$ & 0.19 & 1.00 & & & & & & & & & & \\
\hline TDS & 0.19 & 1.00 & 1.00 & & & & & & & & & \\
\hline $\mathrm{Na}^{+}$ & 0.01 & 0.57 & 0.57 & 1.00 & & & & & & & & \\
\hline $\mathrm{K}^{+}$ & 0.00 & 0.40 & 0.40 & 0.03 & 1.00 & & & & & & & \\
\hline $\mathrm{Ca}^{2+}$ & 0.00 & 0.33 & 0.33 & 0.26 & 0.18 & 1.00 & & & & & & \\
\hline $\mathrm{Cl}^{-}$ & 0.28 & 0.96 & 0.96 & 0.56 & 0.38 & 0.29 & 1.00 & & & & & \\
\hline $\mathrm{TH}$ & 0.11 & 0.67 & 0.67 & 0.12 & 0.52 & 0.27 & 0.64 & 1.00 & & & & \\
\hline TA & -0.14 & -0.36 & -0.36 & -0.18 & -0.09 & 0.02 & -0.51 & -0.40 & 1.00 & & & \\
\hline $\mathrm{HCO}_{3}^{-}$ & -0.17 & -0.32 & -0.32 & -0.27 & -0.11 & -0.02 & -0.43 & -0.15 & 0.48 & 1.00 & & \\
\hline $\mathrm{SO}_{4}^{2-}$ & -0.13 & -0.28 & -0.28 & -0.22 & -0.09 & -0.08 & -0.41 & -0.34 & 0.43 & 0.23 & 1.00 & \\
\hline $\mathrm{Mg}^{2+}$ & 0.10 & 0.42 & 0.42 & -0.05 & 0.38 & -0.39 & 0.42 & 0.78 & -0.39 & -0.13 & -0.28 & 1.00 \\
\hline
\end{tabular}


Table 4. Groundwater classes of Rajnagar aquifer system based on range of index values and concentrations.

\begin{tabular}{|c|c|c|c|c|c|c|}
\hline \multirow[b]{2}{*}{ Parameter } & \multirow[b]{2}{*}{ Range } & \multicolumn{2}{|c|}{ Pre-monsoon $(\mathrm{n}=53)$} & \multicolumn{2}{|c|}{ Post-monsoon $(\mathrm{n}=40)$} & \multirow[b]{2}{*}{ Category } \\
\hline & & No. of samples & Percentage & No. of samples & Percentage & \\
\hline \multicolumn{7}{|c|}{ Domestic potability } \\
\hline $\mathrm{pH}$ & $<6.5$ and $>8.5$ & 53 & 100 & 40 & 100 & Unsafe for drinking \\
\hline $\mathrm{TDS}(\mathrm{mg} / \mathrm{l})$ & $<500$ & 0 & 0 & 0 & 0 & Safe for drinking \\
\hline $\operatorname{TDS}(\mathrm{mg} / \mathrm{l})$ & $500-2000$ & 53 & 100 & 40 & 100 & $>\mathrm{AL}$ for drinking \\
\hline $\operatorname{TDS}(\mathrm{mg} / \mathrm{l})$ & $>2000$ & 0 & 0 & 0 & 0 & $>\mathrm{PL}$ for drinking \\
\hline $\mathrm{TH}(\mathrm{mg} / \mathrm{l})$ & $<75$ & 0 & 0 & 0 & 0 & Soft \\
\hline $\mathrm{TH}(\mathrm{mg} / \mathrm{l})$ & $75-150$ & 24 & 45.3 & 0 & 0 & Moderately hard \\
\hline $\mathrm{TH}(\mathrm{mg} / \mathrm{l})$ & $150-300$ & 29 & 54.7 & 0 & 0 & Hard \\
\hline $\mathrm{TH}(\mathrm{mg} / \mathrm{l})$ & $200-600$ & 3 & 6 & 40 & 100 & $>\mathrm{AL}$ for drinking \\
\hline $\mathrm{TH}(\mathrm{mg} / \mathrm{l})$ & $>600$ & 0 & 0 & 0 & 0 & $>\mathrm{PL}$ for drinking \\
\hline $\mathrm{Ca}^{2+}(\mathrm{mg} / \mathrm{l})$ & $<75$ & 51 & 96.2 & 40 & 100 & Safe for drinking \\
\hline $\mathrm{Ca}^{2+}(\mathrm{mg} / \mathrm{l})$ & $75-200$ & 2 & 3.8 & 0 & 0 & $>\mathrm{AL}$ for drinking \\
\hline $\mathrm{Ca}^{2+}(\mathrm{mg} / \mathrm{l})$ & $>200$ & 0 & 0 & 0 & 0 & $>\mathrm{PL}$ for drinking \\
\hline $\mathrm{Mg}^{2+}(\mathrm{mg} / \mathrm{l})$ & $<30$ & 50 & 94.3 & 5 & 12.5 & Safe for drinking \\
\hline $\mathrm{Mg}^{2+}(\mathrm{mg} / \mathrm{l})$ & $30-100$ & 3 & 5.7 & 35 & 87.5 & $>\mathrm{AL}$ for drinking \\
\hline $\mathrm{Mg}^{2+}(\mathrm{mg} / \mathrm{l})$ & $>100$ & 0 & 0 & 0 & 0 & $>\mathrm{PL}$ for drinking \\
\hline $\mathrm{Cl}^{-}(\mathrm{mg} / \mathrm{l})$ & $<250$ & 50 & 94.3 & 35 & 87.5 & Safe for drinking \\
\hline $\mathrm{Cl}^{-}(\mathrm{mg} / \mathrm{l})$ & $250-1000$ & 3 & 5.7 & 5 & 12.5 & $>$ AL for drinking \\
\hline $\mathrm{Cl}^{-}(\mathrm{mg} / \mathrm{l})$ & $>1000$ & 0 & 0 & 0 & 0 & $>\mathrm{PL}$ for drinking \\
\hline $\mathrm{SO}_{4}^{2-}(\mathrm{mg} / \mathrm{l})$ & $<200$ & 50 & 94.3 & 40 & 100 & Safe for drinking \\
\hline $\mathrm{SO}_{4}^{2-}(\mathrm{mg} / \mathrm{l})$ & $200-400$ & 3 & 5.7 & 0 & 0 & $>\mathrm{AL}$ for drinking \\
\hline $\mathrm{SO}_{4}^{2-}(\mathrm{mg} / \mathrm{l})$ & $>400$ & 0 & 0 & 0 & 0 & $>\mathrm{PL}$ for drinking \\
\hline \multicolumn{7}{|c|}{ Agricultural potability } \\
\hline SAR & $0-6$ & 52 & 98.1 & 38 & 95 & No problem \\
\hline SAR & $6-9$ & 1 & 1.9 & 1 & 2.5 & Increasing problem \\
\hline SAR & $>9$ & 0 & 0 & 1 & 2.5 & Severe problem \\
\hline$\% \mathrm{Na}$ & $<20$ & 0 & 1.1 & 0 & 0 & Excellent \\
\hline$\% \mathrm{Na}$ & $20-40$ & 0 & 3.4 & 0 & 0 & Good \\
\hline$\% \mathrm{Na}$ & $40-60$ & 21 & 33 & 29 & 72.5 & Permissible \\
\hline$\% \mathrm{Na}$ & $60-80$ & 32 & 59.4 & 11 & 35 & Doubtful \\
\hline$\% \mathrm{Na}$ & $>80$ & 0 & 0 & 0 & 0 & Unsuitable \\
\hline $\mathrm{RSC}(\mathrm{meq} / \mathrm{l})$ & $<1.25$ & 51 & 96.2 & 40 & 100 & Safe \\
\hline MR & $<50$ & 32 & 60.4 & 7 & 17.5 & Suitable \\
\hline MR & $>50$ & 21 & 39.6 & 33 & 82.5 & Unsuitable \\
\hline PSS (meq/l) & $<5$ & 47 & 88.7 & 33 & 82.5 & Good \\
\hline PSS (meq/l) & $5-10$ & 5 & 9.4 & 7 & 17.5 & Injurious \\
\hline PSS (meq/l) & $>10$ & 1 & 1.9 & 0 & 0 & Unsatisfactory \\
\hline PI & $<80$ & 16 & 30.18 & 39 & 97.5 & Suitable \\
\hline PI & $>80$ & 37 & 69.8 & 1 & 2.5 & Unsuitable \\
\hline \multicolumn{7}{|c|}{ Industrial potability } \\
\hline $\mathrm{CR}$ & $<1$ & 31 & 58.5 & 22 & 55 & Suitable \\
\hline $\mathrm{CR}$ & $>1$ & 22 & 41.5 & 18 & 45 & Unsuitable \\
\hline $\mathrm{pH}$ & $<7$ & 39 & 73.6 & 0 & 0 & Corrosive \\
\hline $\mathrm{pH}$ & $>7$ & 14 & 26.4 & 40 & 100 & Noncorrosive \\
\hline $\mathrm{EC}(\mu \mathrm{s} / \mathrm{cm})$ & $<1500$ & 49 & 92.5 & 35 & 87.5 & Noncorrosive \\
\hline $\mathrm{EC}(\mu \mathrm{s} / \mathrm{cm})$ & $>1500$ & 4 & 7.5 & 5 & 12.5 & Corrosive \\
\hline $\mathrm{Cl}^{-}(\mathrm{mg} / \mathrm{l})$ & $<500$ & 53 & 100 & 40 & 100 & Noncorrosive \\
\hline $\mathrm{Cl}^{-}(\mathrm{mg} / \mathrm{l})$ & $>500$ & 0 & 0 & 0 & 0 & Corrosive \\
\hline $\mathrm{HCO}_{3}^{-}(\mathrm{mg} / \mathrm{l})$ & $<400$ & 53 & 100 & 40 & 100 & Non-incrusting \\
\hline $\mathrm{HCO}_{3}^{-}(\mathrm{mg} / \mathrm{l})$ & $>400$ & 0 & 0 & 0 & 0 & Soft incrusting \\
\hline $\mathrm{SO}_{4}^{2-}(\mathrm{mg} / \mathrm{l})$ & $<100$ & 53 & 100 & 40 & 100 & Non-incrusting \\
\hline $\mathrm{SO}_{4}^{2-}(\mathrm{mg} / \mathrm{l})$ & $>100$ & 0 & 0 & 0 & 0 & Hard incrusting \\
\hline
\end{tabular}



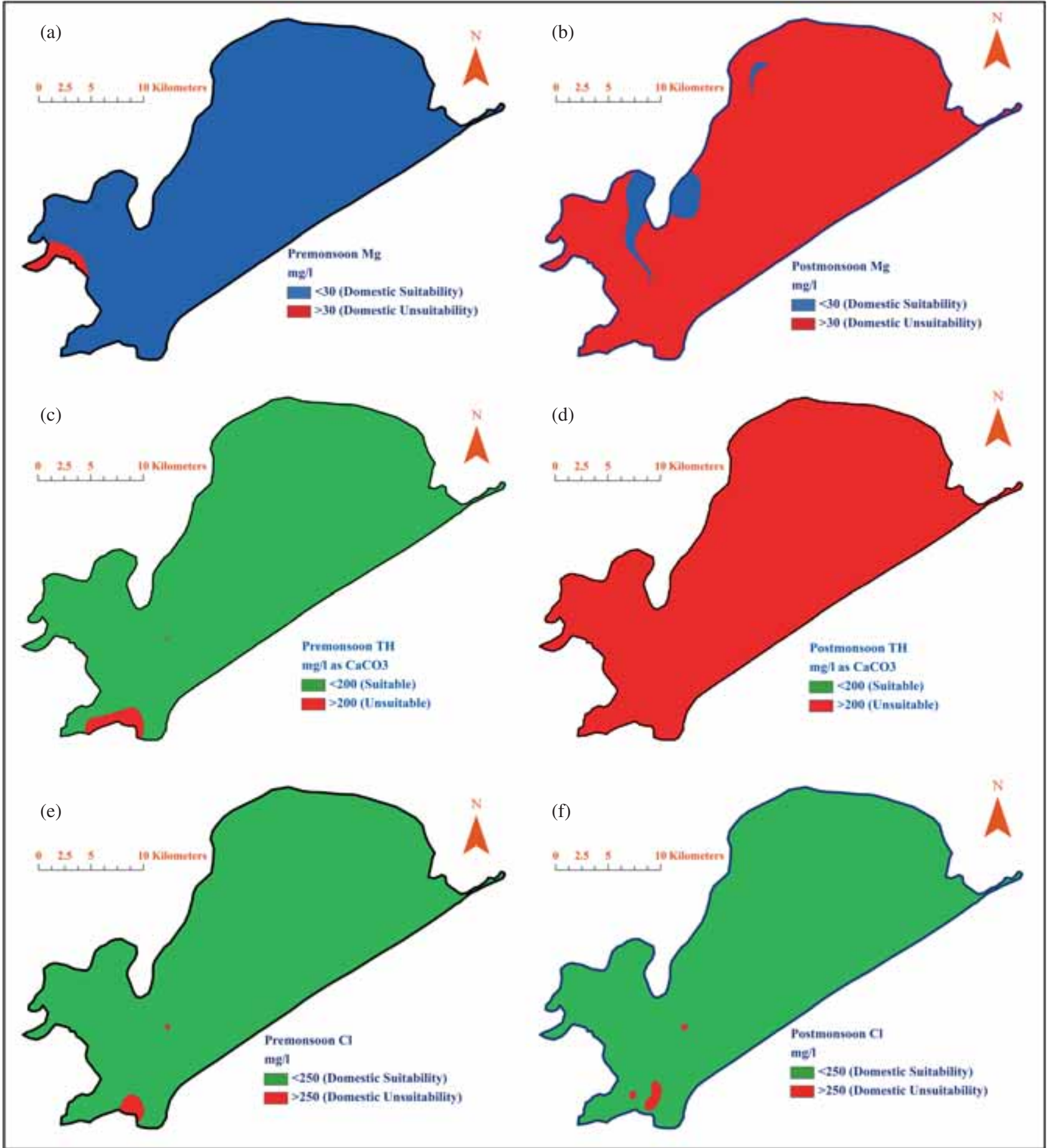

Figure 7. Spatial variation of $\mathrm{Mg}^{2+}$ [(a) pre-monsoon, (b) post-monsoon]; TH [(c) pre-monsoon, (d) post-monsoon] and $\mathrm{Cl}^{-}[(\mathbf{e})$ pre-monsoon, (f) post-monsoon)] activity across the study area.

various ionic proportions of the dominant cations and anions including $\mathrm{Na}^{+}, \mathrm{Ca}^{2+}, \mathrm{Mg}^{2+}$ and $\mathrm{HCO}_{3}^{-}$.

Salinity hazard. While fresh rain water contains minimum salt content, the activity of this keeps on increasing with percolation through the soil horizon to the water table and hence groundwater is known to have a greater concentration of salts than the surface water. This total dissolved solids activity measured in terms of the electrical conductance implies the toxicity towards irrigation use and is expressed as salinity hazard (Wilcox 1955; ICMR 1975). The various classes of water based on TDS activity are low $(<200 \mathrm{mg} / \mathrm{l})$, medium (200-500 mg/l), high (500-1500 mg/l) and very high $(>1500 \mathrm{mg} / \mathrm{l})$. The observation is also in line with the TDS concentration limits as proposed 
by the Food and Agriculture Organization of the United Nations for agricultural potability. Hydrochemistry of the collected groundwater samples portrays profound salinity hazard across the entire study area with all the samples for both the monsoonal season being beyond the threshold limit of $500 \mathrm{mg} / \mathrm{l}$ for agricultural suitability (table 4).

Sodium concentration. One of the chief hydrochemical constituents having significant influence on the utility of the groundwater for irrigation purpose is $\mathrm{Na}^{+}$. Excess $\mathrm{Na}^{+}$is exchanged with soil $\mathrm{Ca}^{2+}$ and $\mathrm{Mg}^{2+}$ causing deflocculation and impairment of soil tilth and permeability (Karanth 1987). This adverse effect of $\mathrm{Na}^{+}$is expressed in terms of sodium hazard where two of the most widely used ionic ratios portraying the quantitativeness are Sodium Adsorption Ratio (SAR) and Percent Sodium $(\% \mathrm{Na})$. The empirical formulae for the above two parameters are given below.

$$
\begin{gathered}
\mathrm{SAR}=\frac{\mathrm{Na}^{+}}{\left(\mathrm{Ca}^{2+}+\mathrm{Mg}^{2+}\right)^{1 / 2}} \\
\% \mathrm{Na}=\frac{\left(\mathrm{Na}^{+}+\mathrm{K}^{+}\right) \times 100}{\left(\mathrm{Ca}^{2+}+\mathrm{Mg}^{2+}+\mathrm{Na}^{+}+\mathrm{K}^{+}\right)}
\end{gathered}
$$

(Here all the activities are expressed in meq/l.)

The threshold limit for the adverse effect of sodium concentration for SAR is 6 (Bouwer 1978) whereas that for the $\% \mathrm{Na}$ is taken as 60 (Eaton 1950; Wilcox 1955; Ramakrishna 1998). The various water classes for SAR values in terms of utility towards irrigation are: 'no problem' (0-6), 'increasing problem' (6-9) and 'severe problem' (>9). The same for the $\% \mathrm{Na}$ categorization are 'excellent to Good' (>20), 'good to permissible' (20-40), 'permissible to doubtful' (40-60), 'doubtful to unsuitable' (60-80) and 'unsuitable' (>80). Groundwater samples of the study area display a relatively safer characteristic during the post-monsoon period for agricultural purpose in regard to $\% \mathrm{Na}$ values. About $60 \%$ of the samples portray a 'doubtful' nature during the pre-monsoon season which is distinctly reduced to $35 \%$ post-monsoon indicating a significant predominance of alkaline earth (table 4). However, SAR values (95\%) show a general suitability towards irrigation for the study area (table 4).

Lateral variability of the $\% \mathrm{Na}$ values displays a significant reduction across the study area during the post-monsoon season except a distinct patch along the western part (figure 8a, b). This observation is in line with the observed higher concentration of $\mathrm{Na}^{+}$along the western margin of the study area. In a similar observation, the western patch also portrays a distinct increase in SAR values during the post-monsoon period (figure $8 \mathrm{c}, \mathrm{d}$ ).
Hence, although the study area displays a general reduction in sodium hazard across the monsoon, the western part of the region displays a distinct unsuitability for agricultural activity with monsoonal precipitation.

Two of the most widely used groundwater classification schemes which take the sodium hazard into consideration are the United States Salinity Laboratory (USSL 1954) diagram and the Wilcox diagram. USSL diagram defines groundwater classes based on the interrelationship between SAR and EC. The various water categories are expressed in terms of sodium hazard and salinity hazard for agriculture utility (figure 8e). The Wilcox diagram (Wilcox 1955) classifies water based on the interrelationship between $\% \mathrm{Na}$ and the total ionic concentration (figure 8f). In a similar manner to the explanation, as stated above, the Wilcox diagram for the study area indicates a distinctly increased suitability for agricultural activity in post-monsoon,with $70 \%$ of the samples coming within the subfield of 'Good to Permissible' category in contrast to $30 \%$ samples during the pre-monsoon season. The USSL diagram depicts a general suitability of the subsurface water for agricultural activity.

Residual sodium carbonate. Residual Sodium Carbonate (RSC) denotes the proportional activity of sodium in terms of excess weak acids over alkaline earth. This excess concentration of weak acids is defined in terms of carbonate and bicarbonate concentrations which is harmful for agriculture beyond the suggested limits (Eaton 1950; Richards 1954). The empirical formula defining the index is given below with units of measurement in meq/l.

$$
\mathrm{RSC}=\left(\mathrm{HCO}_{3}^{-}+\mathrm{CO}_{3}^{2-}\right)-\left(\mathrm{Ca}^{2-}+\mathrm{Mg}^{2+}\right)
$$

With respect to $\mathrm{RSC}$, the collected samples point towards a safer nature of the groundwater for irrigation (table 4). This observation is in sync with the Chadha's and Piper's geochemical classification which displayed a distinct increase in alkaline earth influence on groundwater chemistry during the post-monsoon period. Thus, the small number of samples that indicated deposition of $\mathrm{RSC}$ in pre-monsoon times are practically absent post-monsoon.

Magnesium hazard. Magnesium Hazard (MR) takes into account the relative abundance of $\mathrm{Mg}^{2+}$ with respect to total concentration the total alkaline earth in quantifying potability of groundwater towards agriculture. Empirically, the index is defined as given below with the units of measurement being meq/l.

$$
\mathrm{MR}=\frac{\mathrm{Mg}^{2+} \times 100}{\mathrm{Ca}^{2+}+\mathrm{Mg}^{2+}}
$$



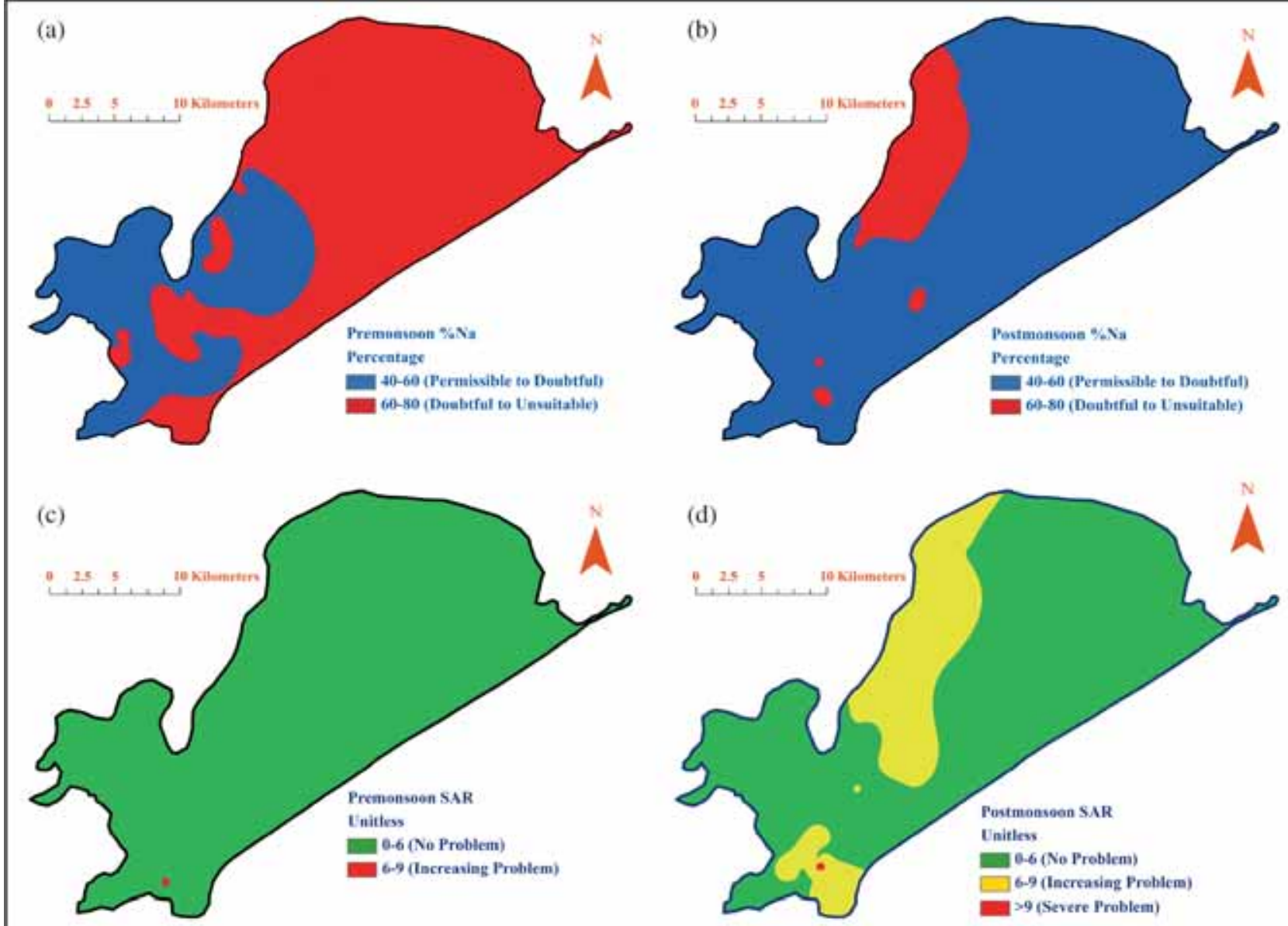

(e)

(f)
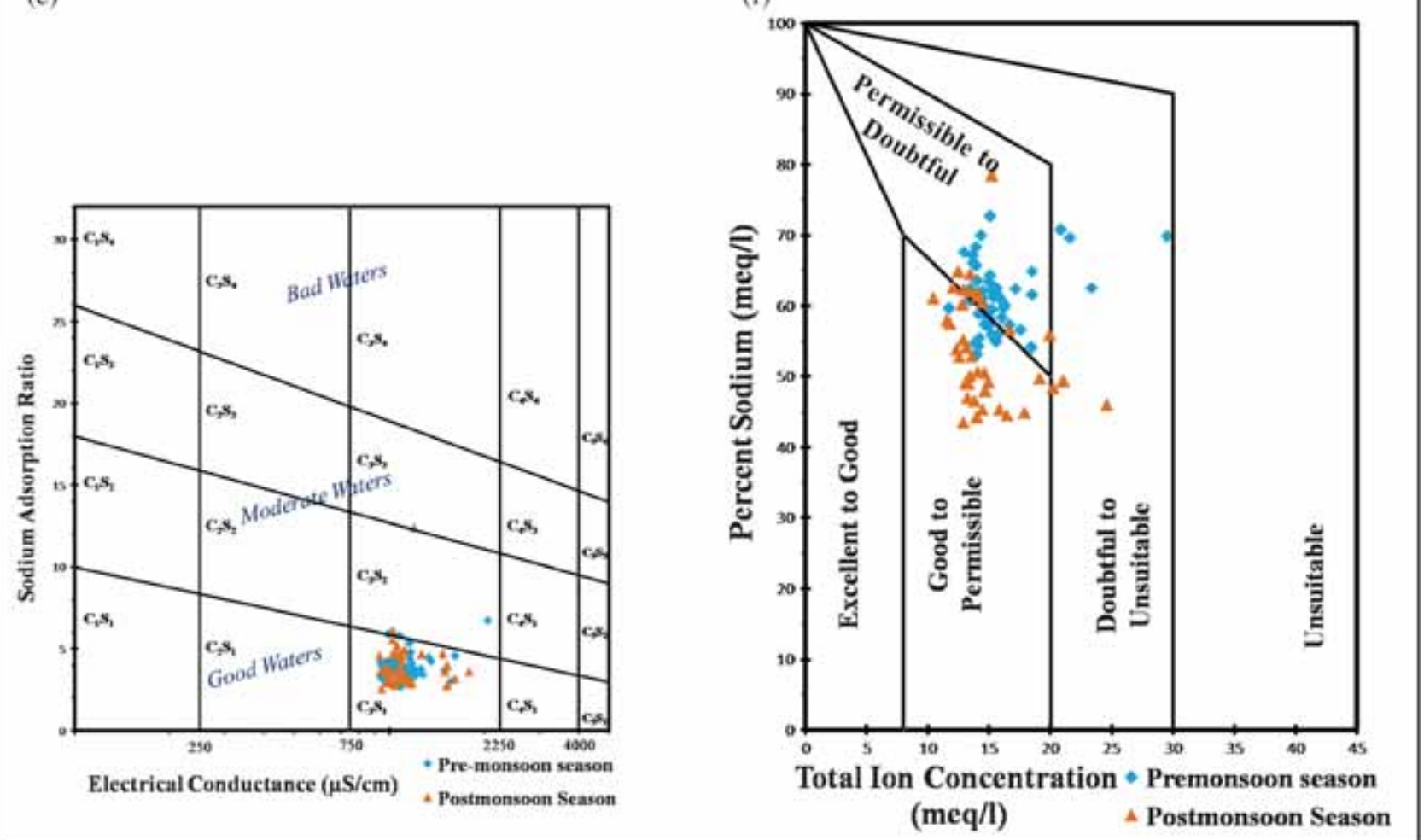

Figure 8. Variation of salinity hazard and sodium hazard of the study area [\% Na (a) pre-monsoon, (b) post-monsoon)] and SAR [(c) pre-monsoon, (d) post-monsoon)] variation of the study area; (e) USSL and (f) Wilcox diagram of the study area groundwater samples. 
Groundwater with MR values in excess of $50 \%$ are characteristically unsafe for irrigation. Hydrochemical analysis of samples portrays a distinct increase in $\mathrm{MR}$ values during the post-monsoon period, making the terrain unsuitable for irrigation. Spatially, the entire study area seems to be reeling under Magnesium hazard except a narrow stretch along the central territory (figure $9 \mathrm{a}, \mathrm{b}$ ).
More than $82 \%$ of the samples exceed the threshold MR value of 50 , post-monsoon, in contrast to $39.6 \%$ during the pre-monsoon season (table 4 ).

Potential soil salinity. The index considers the cumulative influence of strong acids within subsurface water in defining utility towards agriculture. Potential Soil Salinity (PSS) is defined as given

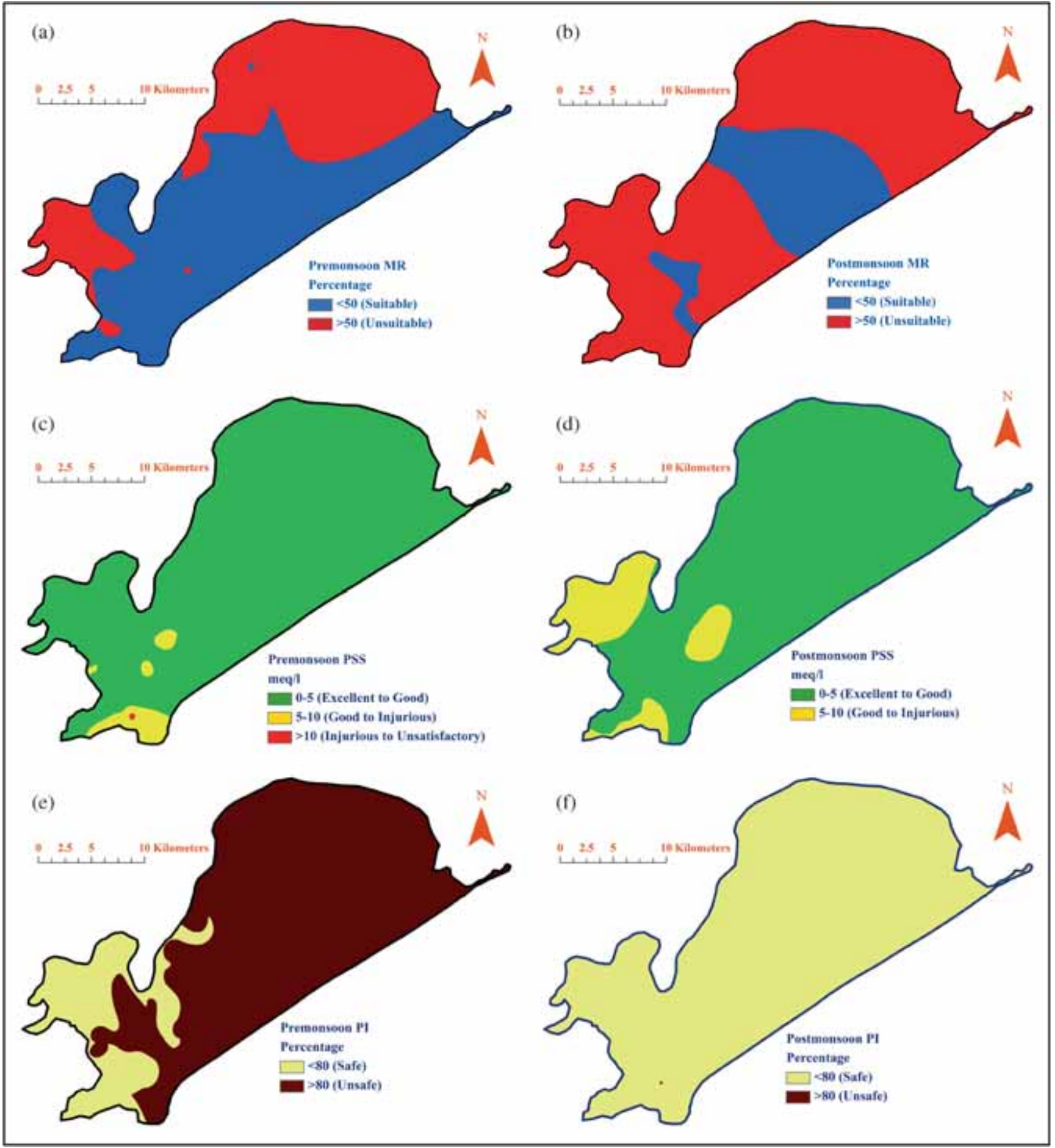

Figure 9. Spatial variation of MR [(a) pre-monsoon, (b) post-monsoon]; PSS (c) pre-monsoon, (d) post-monsoon) and PI $[(\mathbf{e})$ pre-monsoon, (f) post-monsoon)] across the monsoonal season for the study area. 
below, where the unit of measurement is meq/l (Doneen 1962).

$$
\mathrm{PSS}=\mathrm{Cl}^{-}+\left(\frac{\mathrm{SO}_{4}^{2-}}{2}\right)
$$

Analysis of the data is suggestive of a general suitability towards agricultural utility. All the samples, except one pre-monsoonal sample exhibit a PSS value less than 10 for this area (table 4). However, the occurrence of about $9 \%$ of samples pre-monsoon and $17.5 \%$ samples post-monsoon belonging to the 'good to injurious' category indicates a marginally unsafe nature of the subsurface water along the southern part of the study area (figure 9c, d).

Permeability index. Doneen (1964) proposed permeability index (PI) quantifying the permeability of soil for subsurface water which is primarily influenced by alkalis, alkaline earth and weak acids. Quantitatively, the index indicates a relative abundance of alkalis and weak acids (sodium and bicarbonate) to total cations, and is expressed in percentage. The empirical formula for the index is given below, with concentrations expressed in meq/l.

$$
\mathrm{PI}=\frac{\left(\mathrm{Na}^{+}+\sqrt{ } \mathrm{HCO}_{3}^{-}\right) \times 100}{\left(\mathrm{Ca}^{2+}+\mathrm{Mg}^{2+}+\mathrm{Na}^{+}\right)}
$$

Analytical results of the samples indicate a distinct decrease in the number of samples exceeding the threshold value of $80 \%$ from the pre-monsoon $(69.8 \%)$ to the post-monsoon (2.5\%) period (table 4, figure 9e, f). This is primarily due to the increased concentration of $\mathrm{Mg}^{2+}$ during the post-monsoon period which enhances the suitability of the groundwater towards irrigation, when considered in terms of $\mathrm{Na}^{+}$influence.

\subsubsection{Industrial use}

Assessment of industrial potability of the aquifer system is not directly relevant owing to the absence of any industry within the present study area. However, keeping in mind the various proposed industrial projects in and around the study area, quality assessment of the aquifer system with regard to industrial potability has been investigated.

Industrial water quality is broadly evaluated in terms of incrusting and corrosive characteristics (Raghunath 1982; Karanth 1987). Cardinal hydrochemical variables that affect corrosivity of water are $\mathrm{pH}, \mathrm{EC}$ and $\mathrm{Cl}^{-}$. Analysis of data points towards a highly corrosive nature $(73.6 \%$ samples $)$ of the subsurface water with respect to $\mathrm{pH}$ activity during the pre-monsoon season (table 4). However, there is a distinct diminishing trend of corrosivity post-monsoon with no sample displaying a $\mathrm{pH}$ value of less than 7 . Corrosive nature of the subsurface water is quantitatively expressed in terms of corrosivity ratio (CR) that is based on the relative activity of strong acids to weak acids and is expressed as below (Ryner 1944; Raman 1985):

$$
\mathrm{CR}=\frac{\left[\left(\mathrm{Cl}^{-} / 35.5\right)+2\left(\mathrm{SO}_{4}^{2-} / 96\right)\right]}{\left[2\left(\mathrm{HCO}_{3}^{-}+\mathrm{CO}_{3}^{2-}\right) / 100\right]}
$$

where the concentrations are expressed in $\mathrm{mg} / \mathrm{l}$.

Groundwater samples having CR values exceeding 1 are unsuitable for industrial activity because of their corrosive nature. The earlier found unsuitability of the groundwater with respect to $\mathrm{pH}$ concentrations is amply supported by the $\mathrm{CR}$ values which also portray corrosive nature of the aquifer system with more than $40 \%$ of the samples for both the monsoonal periods exceeding the threshold limit of 1 (table 4). However, the aquifer system indicates a general safer characteristic for industrial activity with respect to observed $\mathrm{EC}$ and $\mathrm{Cl}^{-}$ concentrations.

Higher concentration of $\mathrm{HCO}_{3}^{-}(>400 \mathrm{mg} / \mathrm{l})$ and $\mathrm{SO}_{4}^{2-}(>100 \mathrm{mg} / \mathrm{l})$ are the chief source of in crustations in industrial machinery. In crustations of softer nature are produced by the former; whereas those produced by the latter are hard in crustations. The hydrochemistry of the present area indicates the existence of a non-incrusting aquifer system for industrial activity with respect to bicarbonate and sulphate activity.

In a nutshell, the aquifer system in its entirety can be regarded as moderately corrosive but nonincrusting. This contrasting nature of the aquifer system is suggestive of a significant influence of strong acidic anions on the aquifer hydro chemistry. $\mathrm{CR}$, also in an important way, indicates the relative abundance of alkalis and alkaline earth. Thus, the assessed industrial potability confirms the earlier inferences from Chadha's (1999) and Piper's (1944) hydrogeochemical classification for the study area.

\section{Conclusion}

The present study area belongs to the complex coastal Quaternary alluvial tract of Odisha and the concerned aquifer system portrays alternating granular and clayey layers with a diminishing trend of gravels in the eastward direction. Hydrochemical analysis of 93 representative groundwater samples collected across the monsoon indicates a significant influence of aquifer lithology on hydrogeochemistry. However, post-monsoonal activities of variables portray an increasingly distinct influence of evaporation/crystallisation and precipitation processes on the aquifer dynamics. Significant 
variations in various ionic variables across the monsoon indicate the influence of recharging precipitation and the occurrence of a host of hydrogeochemical reactions within the aquifer system. Activities of major cationic variables including $\mathrm{Ca}^{2+}, \mathrm{Na}^{+}, \mathrm{Mg}^{2+}$ and $\mathrm{K}^{+}$give a picture of the widespread prevalence of cation exchange processes, occurring throughout the study area. The spatial disposition of these variables along with the variation of groundwater head level confirms the freshening of the aquifer system in an $\mathrm{S}-\mathrm{N}$ and $\mathrm{SW}-\mathrm{NE}$ direction. There is a significantly increased influx of alkaline earth during the post-monsoon period greatly influencing the hydrogeochemical behaviour of the aquifer system. However, there seems to be an equal disposition of strong and weak acids, during both the monsoonal seasons, signifying the widespread occurrence of acid-base reactions within the subsurface. The consistent concentration and disposition of $\mathrm{Cl}^{-}$across the study area during both the seasons is indicative of significant formational water influences within the subsurface horizons.

Potability evaluation signifies a generally unsafe nature of the subsurface water with regard to domestic, agricultural and industrial activities. Drinking water quality is greatly affected by higher TDS and $\mathrm{Mg}^{2+}$ concentrations. Hydrochemical analysis of the samples also points to widespread hard water regimes across the study area making them unsuitable for various domestic utility. The aquifer system is highly affected by the salinity hazard, sodium hazard and magnesium hazard affecting the groundwater potability towards agricultural use. Industrial potability evaluation of the samples signifies the corrosive nature of the subsurface. However, the analysis does indicate an increased suitability of the aquifer system towards various uses with recharge. It is paramount, however, to keep in mind that the aquifer system is geologically very complex and dynamic. The findings of the present research are based on the analysis of groundwater samples from a single monsoonal season within the scope of the present research. Hence, continuous monitoring and evaluation for multiple seasons will help better appreciate the dynamism of this natural resource.

\section{Acknowledgements}

The authors sincerely acknowledge the facilities and equipment provided by the Department of Geology, Utkal University for carrying out the laboratory and field analysis for this research. The authors are also indebted to the department for the doctoral financial support in purchasing the various chemicals for the laboratory analysis of the collected samples. The authors are thankful to $\mathrm{Mr}$ P K Mohapatra (local resident) and Mr R N Panda (hydrogeologist, RWSS) for their invaluable help, during field data collection.

\section{References}

APHA (American Public Health Association) 1985 Standard methods for the examination of water and waste water; APHA 171134.

Bouwer H 1978 Groundwater Hydrology; McGraw Hill Book Co., New York, 480p.

Brown E, Skougst M W and Fishman M J 1974 Methods for collection and analysis of water samples for dissolved minerals and gases; U.S. Govt. Print. Off. 5160.

BIS (Bureau of Indian Standards) 2012 Indian Standard Drinking Water-Specification, 18p.

CGBG (Central Groundwater Board Government of India) 2002 Hydrogeological framework and development prospects of Kendrapara District, Orissa; Technical Report Series D.

Chadha D K 1999 A proposed new diagram for geochemical classification of natural waters and interpretation of chemical data; Hydrogeol. J. 7(5) 431-439.

Crévecoeur S, Debacker V, Joaquim-Justo C J, Gobert S, Scippo M L, Dejonghe W, Martin P and Thomé J P 2011 Groundwater quality assessment of one former industrial site in Belgium using a TRIAD-like approach; Environ. Pollut. 159 2461-2466.

Das P P and Sahoo H K 2014 A Geospatial Evaluation of SRTM DEM for representative groundwater sampling of Rajnagar Block, Odisha, India; Int. J. Emerg. Technol. Adv. Eng. 4(11) 95-103.

Das P P, Sahoo H K and Mohapatra P P 2016 An integrative geospatial and hydrogeochemical analysis for the assessment of groundwater quality in Mahakalapara Block, Odisha, India; Environ. Earth. Sci. 75(158) 1-18.

Doneen L D 1962 The influence of crop and soil on percolating water; In: Proc. 1961 Biennial Conference on Groundwater Recharge, pp. 156-163.

Doneen L D 1964 Notes on water quality in agriculture; Water science and engineering paper 4001, Dept. Water Science and Engineering, University of California.

Eaton E M 1950 Significance of carbonate in irrigation water; Soil. Sci. 69 123-133.

GSI (Geological Survey of India) 2011 Report on study of coastal processes in Kendrapara and Jagatsinghpur Districts, Orissa; Technical Report, Environmental Geology.

GSI (Geological Survey of India) 2012 Geology and mineral resources of the states of India; Miscellaneous Publication, 30 Part III - Odisha; 92p.

Gibbs R J 1970 Mechanisms controlling world water chemistry; Science 170 1088-1090.

Hem J D 1985 Study and interpretation of the chemical characteristics of natural water; US Geol. Surv. Water Supply Paper, pp. 254-364.

ICMR 1975 Manual of standards of quality for drinking water supplies; Special Report 4427.

Jain C K and Bhatia K K S 1987 Physio-chemical analysis of water and wastewater; User's Manual, U.M.-26, National Institute of Hydrology, Roorkee.

Jianhang L, Chang A C and Laosheng W 2004 Distinguishing sources of groundwater nitrate by ${ }^{1} \mathrm{H}$ NMR of dissolved organic matter; Environ. Pollut. 132 365-374, doi: 10.1016/j.envpol.2004.01.015. 
Karanth K R 1987 Groundwater Assessment, Development and Management; Tata McGraw-Hill, New Delhi, 725p.

Li Y, Li J, Chen S and Diao W 2012 Establishing indices for groundwater contamination risk assessment in the vicinity of hazardous waste landfills in China; Environ. Pollut. 165 77-90, doi: 10.1016/j.envpol.2011.12.042.

Mishra A K, Mohanty B K and Om Prakash 2003 Quaternary sedimentation, stratigraphy and neo-tectonics along the coastal tract and river valleys of Odisha; Proceedings of GEOSAS -IV, pp. 128-133.

Ophori D U and Toth J 1989 Patterns of groundwater chemistry, Ross Creek Basin, Alberta, Canada; Groundwater 27 20-26.

Piper A M 1944 A graphical procedure in the chemical interpretation of ground water analysis; Eos, Trans. Am. Geophys. Union 25(6) 914-923.

Raghunath H M 1982 Groundwater; Willey Eastern Ltd., New Delhi, p. 563.

Ramakrishna 1998 Groundwater Handbook; Kalyani Publishers, Bangalore.

Raman V 1985 Impact of corrosion in the conveyance and distribution of water; J. Indian Water Works Assoc. 11 $115-121$.

Richards L A 1954 Diagnosis and improvement of saline and alkali soils; Agri. Handbook 60, U.S Dept. of Agriculture, p. 160 .
Ryner J W 1944 A new index for determining amount of calcium carbonate scale formed by water; J. Am. Water Assoc. 36 472-486.

Sahoo H K and Mohapatra P P 2010 Degradation of quality of groundwater in Paradeep Area, Jagatsinghpur District, Orissa, India; Int. J. Earth Sci. Eng. 3 56-61.

Shukla N K 2011 Geological and hydrogeological evaluation of the coastal aquifers of Orissa with special reference to the north part of Mahanadi delta; Ph.D. Thesis, Utkal University, 237p.

Shukla N K, Sahoo H K and Acharya S 2010 Assessment of groundwater quality of the coastal aquifers, north of Mahanadi river; Environ. Geochem. 12(1-2) 1-10.

Shukla N K, Sahoo H K and Acharya S 2013 Geological, hydrogeological and hydrochemical attributes of the coastal aquifers of Odisha, India; Int. J. Earth Sci. Eng. 6 1174-1184.

Trivedy R K and Goel P K 1984 Chemical and biological methods for water pollution studies; Env. Publ. Karab, India, 215p.

USSL (United States Salinity Laboratory) 1954 Diagnosis and improvement of saline and alkali soils; U.S. Dept. Agriculture, Hand Book-60, Washington D.C.

Wilcox L V 1955 Classification and use of irrigation water; U.S. Dept. of Agriculture Circular, p. 969.

MS received 15 October 2015; revised 14 March 2016; accepted 4 May 2016

Corresponding editor: RAJIB MAITY 